Short Note

\title{
Aspersymmetide A, a New Centrosymmetric Cyclohexapeptide from the Marine-Derived Fungus Aspergillus versicolor
}

\author{
Xue-Mei Hou ${ }^{1,2,3}$ (D), Ya-Hui Zhang ${ }^{1,2}$, Yang Hai ${ }^{1,2}{ }^{\text {, Ji-Yong Zheng }}{ }^{3}$, Yu-Cheng Gu ${ }^{4}$, \\ Chang-Yun Wang ${ }^{1,2,5, *}$ and Chang-Lun Shao ${ }^{1,2,3, *}$ \\ 1 Key Laboratory of Marine Drugs, The Ministry of Education of China, School of Medicine and Pharmacy, \\ Ocean University of China, Qingdao 266003, China; houxuemei_1990@163.com (X.-M.H.); \\ 15689932652@163.com (Y.-H.Z.); haiyangom@163.com (Y.H.) \\ 2 Laboratory for Marine Drugs and Bioproducts, Qingdao National Laboratory for Marine Science and \\ Technology, Qingdao 266200, China \\ 3 State Key Laboratory for Marine Corrosion and Protection, Luoyang Ship Material Research (LSMRI), \\ Qingdao 266061, China; zhengjy@sunrui.net \\ 4 Syngenta, Jealott's Hill International Research Centre, Bracknell RG42 6EY, Berkshire, UK; \\ yucheng.gu@syngenta.com \\ 5 Institute of Evolution \& Marine Biodiversity, Ocean University of China, Qingdao 266003, China \\ * Correspondence: changyun@ouc.edu.cn (C.-Y.W.); shaochanglun@163.com (C.-L.S.); \\ Tel.: +86-532-8203-1536 (C.-Y.W.); +86-532-8203-1381 (C.-L.S.)
}

Received: 10 October 2017; Accepted: 13 November 2017; Published: 22 November 2017

\begin{abstract}
A new centrosymmetric cyclohexapeptide, aspersymmetide A (1), together with a known peptide, asperphenamate (2), was isolated from the fungus Aspergillus versicolor isolated from a gorgonian coral Carijoa sp., collected from the South China Sea. The chemical structure of 1 was elucidated by analyzing its NMR spectroscopy and MS spectrometry data, and the absolute configurations of the amino acids of $\mathbf{1}$ were determined by Marfey's method and UPLC-MS analysis of the hydrolysate. Aspersymmetide A (1) represents the first example of marine-derived centrosymmetric cyclohexapeptide. Moreover, 1 exhibited weak cytotoxicity against NCI-H292 and A431 cell lines at the concentration of $10 \mu \mathrm{M}$.
\end{abstract}

Keywords: gorgonian-derived fungus; Carijoa sp.; Aspergillus versicolor; centrosymmetric cyclohexapeptide; cytotoxicity

\section{Introduction}

Marine-derived peptides with a hybrid biosynthetic pathway, non-ribosomal peptide synthetases (NRPSs) and polyketide synthetases (PKSs), always show diverse chemicals and activities [1-3]. These peptides provide many prophylactic and curative medicinal drugs with wide bioactivities such as antimalarial, antitumor, antimicrobial, antiviral, and cardioprotective actions [4-6]. Efforts by many research groups focusing on hybrid peptides from marine organisms have been rewarded by the discoveries of novel and bioactive compounds, and some of them have been clinically studied and approved by FDA for disease treatments. For example, the linear peptides E7974 [7], ASG-5ME [8], SGN-75 [9], and CDX-011 [10], cyclic peptide elisidepsin [11], and aplidine [12] are anticancer agents within Stages I-III clinical trials. Besides, SGN-35 [13] and ziconotide [14,15], semi-synthetic and natural peptides for the treatment of cancer and pain, respectively, have been approved by FDA. It has been illustrated that marine-derived peptides with NRPS/PKS biosynthetic pathway may have the great potential as lead compounds for drug development. 
During our research on bioactive metabolites of marine organisms collected from the South China Sea, several bioactive peptides have been isolated from the fungi derived from corals [16-19]. Recently, chemical investigation of the culture of marine-derived fungus Aspergillus versicolor (TA01-14) isolated from a gorgonian Carijoa sp. resulted in the isolation of a new centrally symmetrical NRPS/PKS-derived cyclohexapeptide, aspersymmetide A (1), and a known peptide, asperphenamate (2) [20] (Figure 1). Herein, we report the isolation, structure elucidation, and biological evaluation of these compounds.
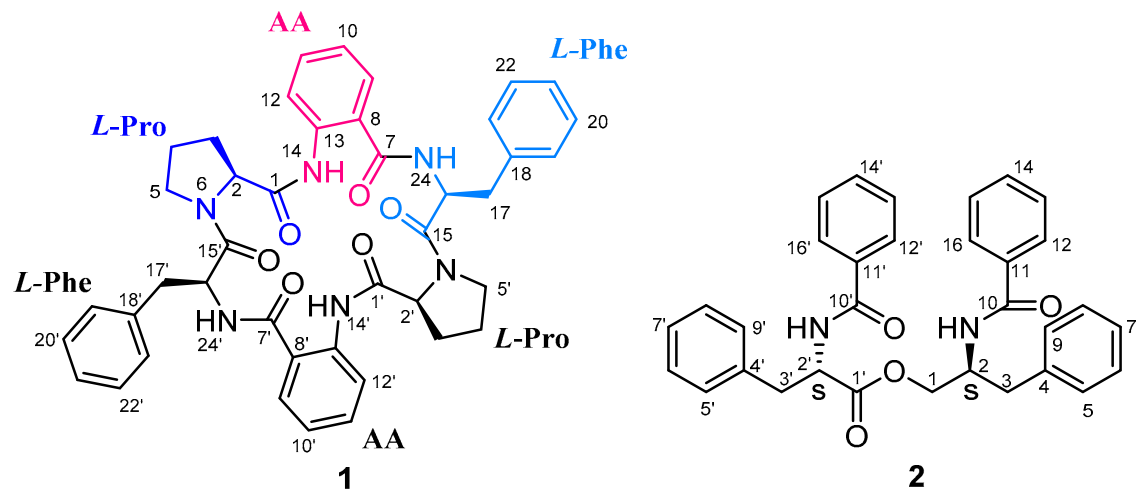

Figure 1. Chemical structures of $\mathbf{1}$ and 2.

\section{Results and Discussion}

Aspersymmetide A (1) was obtained as a white powder. (+)-HRESIMS of $\mathbf{1}$ gave $[\mathrm{M}+\mathrm{H}]^{+}$and $[\mathrm{M}+\mathrm{Na}]^{+}$at $m / z 727.3245$ and 749.3062 , respectively, indicating a molecular formula of $\mathrm{C}_{42} \mathrm{H}_{42} \mathrm{~N}_{6} \mathrm{O}_{6}$ with 25 degrees of unsaturation. The ${ }^{1} \mathrm{H}$ NMR spectrum (Table 1) exhibited two amide $(\mathrm{NH})$ protons at $\delta_{\mathrm{H}}$ 12.23 and 9.10, two $\alpha$-protons of amino acids at $\delta_{\mathrm{H}} 5.24$ and 4.47, one 1,2-disubstituted benzene ring and one mono-substituted benzene ring $\left(\delta_{\mathrm{H}} 6.83-7.89\right)$. The ${ }^{13} \mathrm{C}$ NMR spectrum revealed the presence of three amide carbonyls at $\delta_{\mathrm{C}} 169.8,168.4$, and 167.1, twelve aromatic carbons at $\delta_{\mathrm{C}} 140.2,138.3,132.0,129.6(2 \mathrm{C})$, $127.6(2 \mathrm{C}), 127.5,125.8 .121 .2,117.9$, and 115.1 , and three nitrogen-bearing carbons at $\delta_{\mathrm{C}} 60.5,51.6$, and 46.7 .

Table 1. ${ }^{1} \mathrm{H}$ and ${ }^{13} \mathrm{C}$ NMR (500 and $125 \mathrm{MHz}$, DMSO- $d_{6}$ ) of aspersymmetide A (1).

\begin{tabular}{|c|c|c|c|}
\hline & Position & $\delta_{\mathrm{H}}$, Mult. $(J$ in $\mathrm{Hz})$ & $\delta_{\mathrm{C}}$, Type \\
\hline \multirow{5}{*}{ Pro. } & 1 & & $169.8, \mathrm{C}$ \\
\hline & 2 & $4.47, \mathrm{~d}(8.0)$ & $60.5, \mathrm{CH}$ \\
\hline & 3 & $\begin{array}{l}\mathrm{Ha} 2.21, \mathrm{~m} \\
\mathrm{Hb} 1.72, \mathrm{~m}\end{array}$ & $31.4, \mathrm{CH}_{2}$ \\
\hline & 4 & $\begin{array}{l}\mathrm{Ha} 1.86, \mathrm{~m} \\
\mathrm{Hb} 1.68, \mathrm{~m}\end{array}$ & $20.9, \mathrm{CH}_{2}$ \\
\hline & 5 & $\begin{array}{l}\text { Ha } 3.52, \mathrm{dd}(11.5,8.5) \\
\mathrm{Hb} 3.40, \mathrm{dd}(11.5,10.2)\end{array}$ & $46.7, \mathrm{CH}_{2}$ \\
\hline \multirow{8}{*}{$\mathrm{AA}$} & 7 & & $167.1, \mathrm{C}$ \\
\hline & 8 & & $115.1, \mathrm{C}$ \\
\hline & 9 & $7.89, \mathrm{~d}(8.0)$ & $127.5, \mathrm{CH}$ \\
\hline & 10 & $6.83, \mathrm{t}(8.0)$ & $121.2, \mathrm{CH}$ \\
\hline & 11 & $6.91, t(8.0)$ & $132.0, \mathrm{CH}$ \\
\hline & 12 & $7.74, \mathrm{~d}(8.0)$ & $117.9, \mathrm{CH}$ \\
\hline & 13 & & $140.2, \mathrm{C}$ \\
\hline & $14(\mathrm{NH})$ & $12.23, \mathrm{br} \mathrm{s}$ & \\
\hline \multirow{8}{*}{ Phe. } & 15 & \multirow{4}{*}{$\begin{array}{c}5.24, \mathrm{~m} \\
\text { Ha } 3.21, \mathrm{dd}(13.6,5.1) \\
\text { Hb } 2.87, \text { dd }(13.6,9.5)\end{array}$} & $168.4, \mathrm{C}$ \\
\hline & 16 & & $51.6, \mathrm{CH}$ \\
\hline & 17 & & $37.2, \mathrm{CH}_{2}$ \\
\hline & 18 & & $138.3, \mathrm{C}$ \\
\hline & $19 / 23$ & $7.19, \mathrm{~d}(7.3)$ & $129.6, \mathrm{CH}$ \\
\hline & $20 / 22$ & $7.10, \mathrm{t}(7.3)$ & $127.6, \mathrm{CH}$ \\
\hline & 21 & $7.03, t(7.3)$ & $125.8, \mathrm{CH}$ \\
\hline & $24(\mathrm{NH})$ & $9.10, \mathrm{~d}(9.0)$ & \\
\hline
\end{tabular}


Detailed analysis of 1D and 2D NMR data led to the identification of three units including a proline (Pro.), a phenylalanine (Phe.), and an anthranilic acid (AA) (Figure 2a). However, these three units only were attributed to be half of the proposed molecular formula. It suggested that 1 should be a symmetrical dimer. The HMBC correlations were used to connect the residues in 1. The correlations [Phe-NH $\rightarrow$ AA-CO] and [AA-NH $\rightarrow$ Pro-CO] revealed the half sequence of $\mathrm{CO}-\mathrm{Phe}-\mathrm{NH} \rightarrow \mathrm{CO}-\mathrm{AA}-\mathrm{NH} \rightarrow \mathrm{CO}-\mathrm{Pro}-\mathrm{N}$ (Figure 2). The [Pro- $\alpha-\mathrm{H} \rightarrow$ Phe-CO] connected the two half sequences to establish the whole cyclic structure, cyclo-[CO-Phe-AA-Pro-Phe-AA-Pro-N]. Additional evidence confirmed the structure of 1 on the basis of the ESI MS ${ }^{2}$ experiments with neutral losses (Figure 3 and Figure S14). Thus, the planar structure of $\mathbf{1}$ was determined as shown in Figure $2 \mathrm{~b}$.

The absolute configurations of the amino acids in $\mathbf{1}$ were determined by UPLC-MS analysis of the acid hydrolysate derivatized with Marfey's reagent ( $N^{\alpha}$-(2,4-dinitro-5-fluorophenyl)-L-alalinamide, L-FDAA) [21]. The retention times and negative ESIMS indicated the presence of L-Pro and L-Phe in 1 (see Experimental and Figure S16). Thus, the absolute configuration of $\mathbf{1}$ was determined as shown in Figure 1. These structural features revealed that aspersymmetide A (1) is a centrally symmetric cyclohexapeptide.
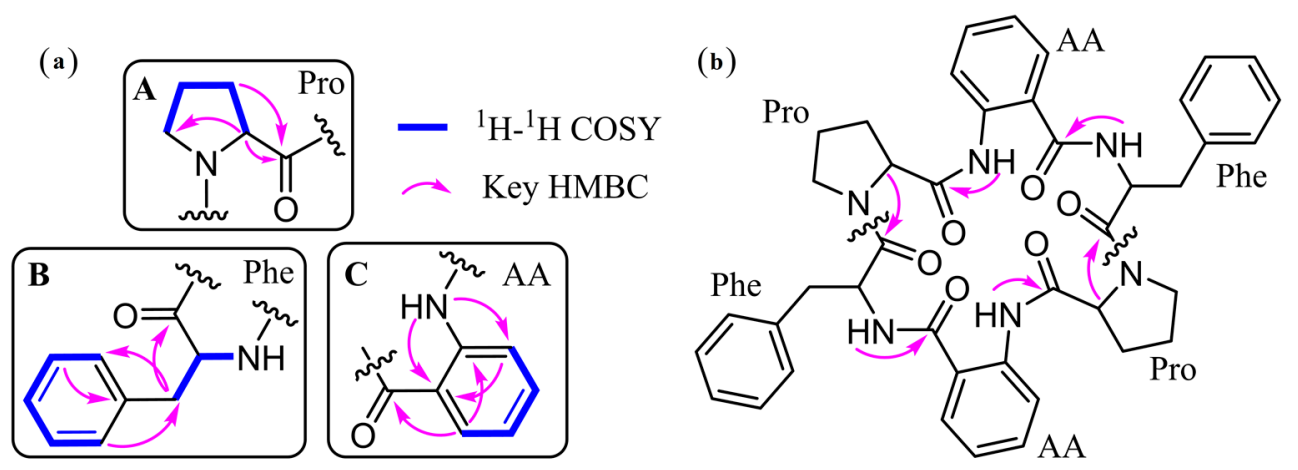

Figure 2. ${ }^{1} \mathrm{H}-{ }^{1} \mathrm{H}$ COSY and key HMBC correlations of 1. (a) Residues in 1. (b) The connection of the residues.

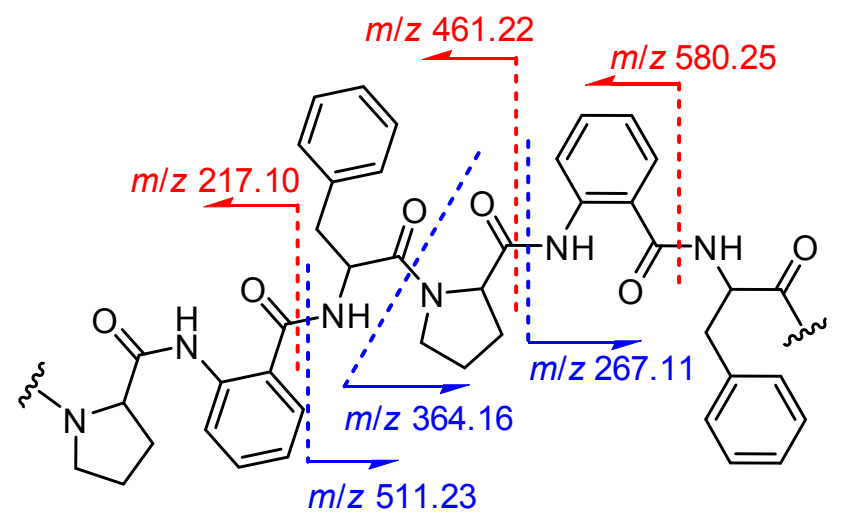

Figure 3. ESI MS² fragment ions for 1.

Centrosymmetric cyclopeptides (CSCs) are an important class of peptides that always show diverse bioactivities, such as the enniatins [22] with antibiotic, antifungal, antiinsectan, and cytotoxic activities, and PF1022 [23] with anthelmintic activity. Particularly, fusafungine [24], a mixture of enniatins, has been an active agent used in antibiotics for treatment of nasal and throat infection; emodepdide, the bis-para morpholino-PF1022A, has been introduced into the market as a broad spectrum anthelmintic [25]. A literature survey revealed that the majority of CSCs are synthetic [26-29], while only a few have been found in natural sources, including cyclohexadepsipeptides (3-10) [22,30-40] and 
cyclooctadepsipeptides (11-14) [25,34,41-44] (Table 2, Figure S17). Compounds 3-13 were obtained from terrestrial microorganisms, and $\mathbf{1 4}$ was isolated from the marine-derived bacterium Micromonospora sp. aspersymmetide A (1) represents the first example of centrally symmetric cyclohexapeptide from marine organisms.

Table 2. Natural products of centrosymmetric cyclopeptides (CSCs).

\begin{tabular}{|c|c|c|c|c|}
\hline Compd. & Collected Source & $\begin{array}{l}\text { Biosynthetic } \\
\text { Source }\end{array}$ & Bioactivity & Reference \\
\hline Enniatin A (3) & \multirow{5}{*}{ Fungus } & Fusarium sp. & & {$[22,30,31]$} \\
\hline Enniatin B (4) & & Verticillium sp. & & {$[22,32]$} \\
\hline Enniatin C (5) & & Verticillium $\mathrm{sp}$. & Anti-mycotoxigenic fungi & {$[22,32]$} \\
\hline Enniatin MK1688 (6) & & Fusarium oxysporum & & {$[22,33]$} \\
\hline Verticilide B1 (7) & & Verticillium $\mathrm{sp}$ & Acyl-CoA:cholesterol acyltransferase inhibition & [34] \\
\hline Himastatin (8) & Actinomycete & $\begin{array}{l}\text { Streptomyces } \\
\text { hygroscopicus }\end{array}$ & Cytotoxic activity & [35-37] \\
\hline Beauvericin $(9)$ & \multirow{5}{*}{ Fungus } & Fusarium oxysporum & Cytotoxic and antiangiogenic activities & {$[38]$} \\
\hline Hirsutellide A (10) & & Hirsutella kobayasii & Antibacterial and antimalarial activities & [39] \\
\hline Verticilide A1 (11) & & Verticillium sp. & Acyl-CoA:cholesterol acyltransferase inhibition & [34] \\
\hline Bassianolide (12) & & Beauveria bassiana & Insecticidal activity & {$[41-43]$} \\
\hline PF1022A (13) & & Ascaridia galli & Anthelmintic activity & [25] \\
\hline Thiocoraline (14) & Actinomycete & Micromonospora sp. & Cytotoxic and antimicrobial activities & [44] \\
\hline
\end{tabular}

Aspersymmetide A (1) was evaluated for brine shrimp lethality against Artemia salina, for cytotoxicity against the human breast cancer (MCF-7), human pulmonary carcinoma (NCI-H292), and human skin squamous carcinoma (A-431) cell lines, for antibacterial activity against Staphylococcus albus and Escherichia coli, for antiviral activity against the human cytomegalovirus (HCMV) and herpes simplex virus (HSV-1), and for enzymic inhibition toward acetyl cholinesterase (AChE), Top I, and $\alpha$-glucosacharase. It displayed weak cytotoxicity against NCI-H292 and A431 cells with an inhibition ratio of $53.84 \%$ and $63.62 \%$ at a concentration of $10 \mu \mathrm{M}$ (adriamycin, $1 \mu \mathrm{M}, 93.36 \%$ and $91.00 \%$ ). However, 1 was inactive in other bioassays.

\section{Materials and Methods}

\subsection{General Experimental Procedures}

Optical rotations were measured on a JASCO P-1020 digital polarimeter (JASCO Ltd., Tokyo, Japan). IR spectra were recorded on a Nicolet-Nexus-470 spectrometer (Perkin Elmer Ltd., Boston, MA, USA) using KBr pellets. NMR spectra were recorded on a JEOL JEM-ECP NMR spectrometer (JEOL Ltd., Tokyo, Japan; $500 \mathrm{MHz}$ for ${ }^{1} \mathrm{H}$ and $125 \mathrm{MHz}$ for ${ }^{13} \mathrm{C}$ ), using TMS as internal standard. The ESIMS spectra were obtained from a Micromass Q-TOF spectrometer (Waters Ltd., Boston, MA, USA). Semi-preparative HPLC was performed on a Hitachi L-2000 system (Hitachi Ltd., Tokyo, Japan) using a C18 column (Kromasil (Eka Ltd., Bohus, Sweden) $250 \times 10 \mathrm{~mm}, 5 \mu \mathrm{m}, 2.0 \mathrm{~mL} / \mathrm{min}$ ). UPLC-MS was performed on Waters UPLC ${ }^{\circledR}$ system (Waters Ltd., Boston, MA, USA) using a C18 column (ACQUITY UPLC ${ }^{\circledR}$ (Waters Ltd., Boston, MA, USA) BEH C18, $2.1 \times 50 \mathrm{~mm}, 1.7 \mu \mathrm{m} ; 0.5 \mathrm{~mL} / \mathrm{min}$ ) and ACQUITY QDa ESIMS scan from 150 to $1000 \mathrm{Da}$. Silica gel (Qingdao Haiyang Chemical Group Co., Qingdao, China; 200-300 mesh), octadecylsilyl silica gel (YMC Co., Ltd., Tokyo, Japan; 45-60 $\mu \mathrm{m}$ ), and Sephadex LH-20 (GE Ltd., Hartford, CT, USA) were used for column chromatography (CC). Precoated silica gel plates (Yantai Zhifu Chemical Group Co., Yantai, China; G60, F-254) were used for thin layer chromatography.

\subsection{Fungal Material}

The fungus Aspergillus versicolor (TA01-14) was isolated from a gorgonian Carijoa sp. (GX-WZ-2010001) collected from the Weizhou coral reefs in the South China Sea in April 2010. The strain was deposited at the Key Laboratory of Marine Drugs, the Ministry of Education of China, School of Medicine and Pharmacy, Ocean University of China, Qingdao, China, with the Genbank (NCBI) accession number KP759287. 


\subsection{Fermentation, Extraction, and Isolation}

The fungus was cultured on rice solid medium (fifty $1000 \mathrm{~mL}$ Erlenmeyer flasks, each containing $50 \mathrm{~g}$ of rice and $50 \mathrm{~mL}$ of sea water) at room temperature. After 60 days of cultivation, the fermented rice substrate was extracted three times with ethyl acetate (EtOAc) $(200 \mathrm{~mL}$ per flask) to give an organic extract $(10 \mathrm{~g})$. The extract was subjected to a silica gel column chromatography (CC) and eluted by a gradient of petroleum ether (PE)-EtOAc (PE, 100\%-0), EtOAc-MeOH (v:v, 9:1), and then $\mathrm{MeOH}$ to afford eight fractions (Fr.1-Fr.8) on the basis of TLC analysis. Fr.5 was applied over CC of silica gel with PE-EtOAC $(\mathrm{PE}, 70 \%-0)$ to afford three sub-fractions (Fr.5-1-Fr.5-3). Fr.5-3 was then subjected to Sephadex LH-20 $\mathrm{CC}$ and eluted with a mixture of $\mathrm{CH}_{2} \mathrm{Cl}_{2}-\mathrm{MeOH}$ (v:v, 1:1) to obtain two sub-fractions (Fr.5-3-1-Fr.5-3-2). Fr.5-3-1 was then repeatedly separated by silica gel and ODS column chromatography, and then purified by HPLC ( $\left.\mathrm{MeOH}-\mathrm{H}_{2} \mathrm{O}, 75-25\right)$ to afford Compounds $\mathbf{1}(3 \mathrm{mg})$ and 2 (2 mg).

Aspersymmetide A (1): white powder; $[\alpha]_{\mathrm{D}}^{24}-174.2$ (c 0.80, MeOH); UV (MeOH) $\lambda_{\max }(\log \varepsilon)$ 206 (4.01), 227 (3.90), 271 (3.34) nm; IR (KBr) $v_{\max } 3441,1632$, and $1399 \mathrm{~cm}^{-1} ;{ }^{1} \mathrm{H}$ and ${ }^{13} \mathrm{C}$ NMR see Table 1; ESI MS ${ }^{2}$ (fragmentation of $m / z 727.52[\mathrm{M}+\mathrm{H}]^{+}$) $m / z 580.25[\mathrm{M}-\mathrm{Phe}+\mathrm{H}]^{+}$, $511.23[\mathrm{M}-\text { Pro }-\mathrm{AA}+\mathrm{H}]^{+}, 461.22[\mathrm{M}-\mathrm{Phe}-\mathrm{AA}+\mathrm{H}]^{+}, 364.16[\mathrm{M}-\text { Pro }-\mathrm{AA}-\text { Phe }+\mathrm{H}]^{+}$, 267.11 [M - Pro - AA - Phe - Pro + H] ${ }^{+}, 217.10[\mathrm{M}-\text { Phe - AA - Pro - Phe + H] }]^{+}$; HRESIMS $\mathrm{m} / z$ $727.3245[\mathrm{M}+\mathrm{H}]^{+}, 749.3062[\mathrm{M}+\mathrm{Na}]^{+}$(calcd. for $\mathrm{C}_{42} \mathrm{H}_{43} \mathrm{~N}_{6} \mathrm{O}_{6}, 727.3239[\mathrm{M}+\mathrm{H}]^{+}, \mathrm{C}_{42} \mathrm{H}_{42} \mathrm{~N}_{6} \mathrm{O}_{6} \mathrm{Na}$, $\left.749.3058[\mathrm{M}+\mathrm{Na}]^{+}\right)$.

The structure of 2 was assigned by spectroscopic method and comparison of the ${ }^{1} \mathrm{H}$ - and ${ }^{13} \mathrm{C}-\mathrm{NMR}$ data (see Supplementary Information) with those reported in the literature [20].

\subsection{Acid Hydrolysis and Marfey's Analysis of $\mathbf{1}$}

A solution of $1(0.5 \mathrm{mg})$ with $\mathrm{HCl}(6 \mathrm{M}, 1 \mathrm{~mL})$ was hydrolyzed by heating for $20 \mathrm{~h}$ at $110{ }^{\circ} \mathrm{C}$. The solution was evaporated to dryness under vacuum and redissolved in $\mathrm{H}_{2} \mathrm{O}(250 \mu \mathrm{L})$. The acid hydrolysate solution $(50 \mu \mathrm{L})$ was treated with $1 \%$ solution of L-FDAA $(20 \mu \mathrm{L})$ in acetone followed by a solution of $\mathrm{NaHCO}_{3}(1 \mathrm{M}, 10 \mu \mathrm{L})$. The mixture was heated at $40^{\circ} \mathrm{C}$ for $1 \mathrm{~h}$. The reaction was stopped by $\mathrm{HCl}(2 \mathrm{M}, 5 \mu \mathrm{L}$ ). The standards of amino acids (L-Pro, L/D-Pro, L-Phe, and L/D-Phe) were derivatized with L-FDAA in the same manner as that of 1 . All L-FDAA derivatives were analyzed and detected by UPLCMS (ACQUITY UPLC ${ }^{\circledR}$ (Waters Ltd., Boston, MA, USA)) BEH C18, $2.1 \times 50$ mm, $1.7 \mu \mathrm{m}$; solvents: MeCN (A), $\mathrm{H}_{2} \mathrm{O}(0.1 \% \mathrm{HCOOH})(B)$; linear gradient: 0-13 min, 5-50\% A; 13-15 min, 50-100\% A; 15-17 min, $100 \%$ A; $17-18 \mathrm{~min}, 100-5 \%$ A; $18-20 \mathrm{~min}, 5 \%$ A; flow rate: $0.5 \mathrm{~mL} / \mathrm{min}$; monitor: $190-700 \mathrm{~nm}$; ESI MS scan: 150-1000 Da). Retention times (min) and ESI MS of the amino acid derivatives were recorded as follows: L-FDAA-L-Pro $6.24 \mathrm{~min}$, L-FDAA-D-Pro $\left.6.81 \mathrm{~min}(\mathrm{~m} / z 367.1 \text { [M - H] }]^{-}\right)$, L-FDAA-L-Phe $8.92 \mathrm{~min}$, L-FDAA-D-Phe $9.99 \min \left(m / z 417.1[\mathrm{M}-\mathrm{H}]^{-}\right)$(Figure S14).

\subsection{Biological Assay}

Brine shrimp lethality against Artemia salina was evaluated using the modified Reed-Muench method [45], with doxorubicin as a positive control [46]. Cytotoxic activity was evaluated against the MCF-7, NCI-H292, and A-431 cell lines by the MTT method [47], with adriamycin as a positive control. Antibacterial activity against $S$. albus and E. coli was evaluated by using 96 -well microtiter plates [48], with ciprofloxacin as a positive control. Antiviral activity against HCMV and HSV-1 was evaluated by the cytopathic effect (CPE) inhibition assay by the MTT method [47], with cidofovir and acyclovir as positive controls, respectively. AChE inhibition was determined spectrophotometrically using acetylthiocholine iodide (ATCI) as substrate by modified Ellman method [49], with huperzine A and galantamine hydrobromide as positive controls. Top I inhibiting activity was tested on the basis of DNA relaxation experiment [50], with 10-hydroxy camptothecin (OPT) as a positive control. $\alpha$-Glucosacharase inhibiting activity was evaluated by the Dewi's method [51], with acarbose as a positive control. 


\section{Conclusions}

A new centrosymmetric cyclopeptide, aspersymmetide A (1), was obtained from the gorgonian-derived fungal strain Aspergillus versicolor (TA01-14). Compound 1 represents the first example of marine-derived centrosymmetric cyclohexapeptide with weak cytotoxicity.

Supplementary Materials: Supplementary materials according to this paper are available online at www.mdpi. com/1660-3397/15/11/363/s1.

Acknowledgments: We thank Syngenta for the fellowship to X.-M.H. This work was supported by the Outstanding Youth Natural Science Foundation of Shandong Province of China (No. JQ201510), the Program of National Natural Science Foundation of China (Nos. 41376145, 41322037, 41606172 and U1606403), the AoShan Talents Program Supported by the Qingdao National Laboratory for Marine Science and Technology (No. 2015ASTP-ES11), the Research Fund of State Key Laboratory for Marine Corrosion and Protection of Luoyang Ship Material Research Institute (LSMRI) [No. KF160411], and the Taishan Scholars Program, China.

Author Contributions: Xue-Mei Hou contributes to extraction, isolation, identification, and manuscript preparation; Ya-Hui Zhang and Ji-Yong Zheng contribute to bioactivity tests; Yang Hai contributes to supplementary data preparation; Chang-Yun Wang, Chang-Lun Shao, and Yu-Cheng Gu are the project leaders organizing and guiding the experiments and manuscript writing.

Conflicts of Interest: The authors declare no conflict of interest.

\section{References}

1. Donadio, S.; Monciardini, P.; Sosio, M. Polyketide synthases and nonribosomal peptide synthetases: The emerging view from bacterial genomics. Nat. Prod. Rep. 2007, 24, 1073-1109. [CrossRef] [PubMed]

2. Russell, J.C. Polyketides, proteins and genes in fungi: Programmed nano-machines begin to reveal their secrets. Org. Biomol. Chem. 2007, 5, 2010-2026.

3. Fischbach, M.A.; Walsh, C.T. Assembly-line enzymology for polyketide and nonribosomal peptide antibiotics: Logic, machinery, and mechanisms. Chem. Rev. 2006, 106, 3468-3496. [CrossRef] [PubMed]

4. Molinski, T.F.; Dalisay, D.S.; Lievens, S.L.; Saludes, J.P. Drug development from marine natural products. Nat. Rev. Drug Discov. 2009, 8, 69-85. [CrossRef] [PubMed]

5. Lamberth, C. Naturally occurring amino acid derivatives with herbicidal, fungicidal or insecticidal activity. Amino Acids 2016, 48, 929-940. [CrossRef] [PubMed]

6. Liu, S.X.; Gu, W.X.; Lo, D.; Ding, X.Z.; Ujiki, M.; Adrian, T.E.; Soff, G.A.; Silverman, R.B. $\mathrm{N}$-Methylsansalvamide A peptide analogues, potent new antitumor agents. J. Med. Chem. 2005, 48, 3630-3638. [CrossRef] [PubMed]

7. Rocha-Lima, C.M.; Bayraktar, S.; MacIntyre, J.; Raez, L.; Flores, A.M.; Ferrell, A.; Rubin, E.H.; Poplin, E.A.; Tan, A.R.; Lucarelli, A.; et al. A phase 1 trial of E7974 administered on day 1 of a 21-day cycle in patients with advanced solid tumors. Cancer 2012, 118, 4262-4270. [CrossRef] [PubMed]

8. Mattie, M.; Raitano, A.; Morrison, K.; Morrison, K.; An, Z.; Capo, L.; Verlinsky, A.; Leavitt, M.; Ou, J.; Nadell, R.; et al. The discovery and preclinical development of ASG-5ME, an antibody-drug conjugate targeting SLC44A4-positive epithelial tumors including pancreatic and prostate cancer. Mol. Cancer Ther. 2016, 15, 2679-2687. [CrossRef] [PubMed]

9. Tannir, N.M.; Forero-Torres, A.; Ramchandren, R.; Pal, S.K.; Ansell, S.M.; Infante, J.R.; de Vos, S.; Hamlin, P.A.; Kim, S.K.; Whiting, N.C.; et al. Phase I dose-escalation study of SGN-75 in patients with CD70-positive relapsed/refractory non-Hodgkin lymphoma or metastatic renal cell carcinoma. Investig. New Drugs 2014, 32, 1246-1257. [CrossRef] [PubMed]

10. Kolb, E.A.; Gorlick, R.; Billups, C.A.; Hawthorne, T.; Kurmasheva, R.T.; Houghton, P.J.; Smith, M.A. Initial testing (stage 1) of glembatumumab vedotin (CDX-011) by the pediatric preclinical testing program. Pediatr. Blood Cancer 2014, 61, 1816-1821. [CrossRef] [PubMed]

11. Petty, R.; Anthoney, A.; Metges, J.P.; Alsina, M.; Goncalves, A.; Brown, J.; Montagut, C.; Gunzer, K.; Laus, G.; Iglesias Dios, J.L.; et al. Phase Ib/II study of elisidepsin in metastatic or advanced gastroesophageal cancer (IMAGE trial). Cancer Chemother. Pharm. 2016, 77, 819-827. [CrossRef] [PubMed]

12. Barboza, N.M.; Medina, D.J.; Budak-Alpdogan, T.; Aracil, M.; Jimeno, J.M.; Bertino, J.R.; Banerjee, D. Plitidepsin (Aplidin) is a potent inhibitor of diffuse large cell and Burkitt lymphoma and is synergistic with rituximab. Cancer Biol. Ther. 2012, 13, 114-122. [CrossRef] [PubMed] 
13. Katz, J.; Janik, J.E.; Younes, A. Brentuximab Vedotin (SGN-35). Clin. Cancer Res. 2011, 17, $6428-6436$. [CrossRef] [PubMed]

14. Teichert, R.W.; Olivera, B.M. Natural products and ion channel pharmacology. Future Med. Chem. 2010, 2, 731-744. [CrossRef] [PubMed]

15. Daly, N.L.; Craik, D.J. Conopeptides as novel options for pain management. Drugs Future 2011, 36, $25-32$. [CrossRef]

16. Chen, M.; Shao, C.L.; Fu, X.M.; Xu, R.F.; Zheng, J.J.; Zhao, D.L.; She, Z.G.; Wang, C.Y. Bioactive indole alkaloids and phenyl ether derivatives from a marine-derived Aspergillus sp. Fungus. J. Nat. Prod. 2013, 76, 547-553. [CrossRef] [PubMed]

17. Shao, C.L.; Xu, R.F.; Wang, C.Y.; Qian, P.Y.; Wang, K.L.; Wei, M.Y. Potent Antifouling marine dihydroquinolin-2(1H)-one-containing alkaloids from the gorgonian coral-derived fungus Scopulariopsis sp. Mar. Biotechnol. 2015, 17, 408-415. [CrossRef] [PubMed]

18. Zheng, C.J.; Shao, C.L.; Wu, L.Y.; Chen, M.; Wang, K.L.; Zhao, D.L.; Sun, X.P.; Chen, G.Y.; Wang, C.Y. Bioactive phenylalanine derivatives and cytochalasins from the soft coral-derived fungus, Aspergillus elegans. Mar. Drugs 2013, 11, 2054-2068. [CrossRef] [PubMed]

19. Chen, M.; Shao, C.L.; Fu, X.M.; Kong, C.J.; She, Z.G.; Wang, C.Y. Lumazine peptides penilumamides B-D and the cyclic pentapeptide asperpeptide A from a gorgonian-derived Aspergillus sp. fungus. J. Nat. Prod. 2014, 77, 1601-1606. [CrossRef] [PubMed]

20. Chang, R.J.; Wang, C.H.; Zeng, Q.; Guan, B.; Zhang, W.D.; Jin, H.Z. Chemical constituents of the stems of Celastrus rugosus. Arch. Pharm. Res. 2013, 36, 1291-1301. [CrossRef] [PubMed]

21. Marfey, P. Determination of D-amino acids. II. Use of a bifunctional reagent, 1,5-difluoro-2,4-dinitrobenzene. Carlsberg Res. Commun. 1984, 49, 591-596. [CrossRef]

22. Sy-Cordero, A.A.; Pearce, C.J.; Oberlies, N.H. Revisiting the enniatins: A review of their isolation, biosynthesis, structure determination and biological activities. J. Antibiot. 2012, 65, 541-549. [CrossRef] [PubMed]

23. Sakanaka, O.; Okada, Y.; Ohyama, M.; Matsumoto, M.; Takahashi, M.; Murai, Y.; Iinuma, K.; Harder, A.; Mencke, N. Novel Cyclic Depsipeptide PF1022A Derivatives. Patent WO97/11064, 27 March 1997.

24. European Food Safety Authority (EFSA). Scientific opinion on the risks to human and animal health related to the presence of beauvericin and enniatins in food and feed. EFSA J. 2014, 12, 3802.

25. Sasaki, T.; Takagi, M.; Yaguchi, T.; Miyadoh, S.; Okada, T.; Koyama, M. A new anthelmintic cyclodepsipeptide, PF1022A. J. Antibiot. 1992, 45, 692-697. [CrossRef] [PubMed]

26. Madison, V.; Deber, C.M.; Blout, E.R. Cyclic peptides. 17. Metal and amino acid complexes of cyclo(Pro-Gly) 4 and analogs studied by nuclear magnetic resonance and circular dichroism. J. Am. Chem. Soc. 1977, 99, 4788-4798. [CrossRef] [PubMed]

27. Mizuno, H.; Lee, S.; Nakamura, H.; Kato, T.; Go, N.; Izumiya, N. Conformational and energy analyses of proline-containing model peptides for $\beta$-turn. Peptide Chem. 1984, 21, 145-150.

28. Kessler, H.; Bats, J.W.; Griesinger, C.; Koll, S.; Will, M.; Wagner, K. Peptide conformations. 46. Conformational analysis of a superpotent cytoprotective cyclic somatostatin analog. J. Am. Chem. Soc. 1988, 110, 1033-1049. [CrossRef]

29. Ishizu, T.; Fujii, A.; Noguchi, S. Conformational studies of cyclo(L-Phe-L-Pro-Gly-L-Pro) 2 by carbon-13 nuclear magnetic resonance. Chem. Pharm. Bull. 1991, 39, 1617-1619. [CrossRef] [PubMed]

30. Gaumann, E.; Roth, S.; Ettlinger, L.; Plattner, P.A.; Nager, U. Enniatin, a new antibiotic active against Mycobacteria. Experientia 1947, 3, 202-203. [PubMed]

31. Blais, L.A.; Apsimon, J.W.; Blackwell, B.A.; Greenhalgh, R.; Miller, J.D. Isolation and characterization of enniatins from Fusarium avenaceum DAOM 196490. Can. J. Chem. 1992, 70, 1281-1287. [CrossRef]

32. Supothina, S.; Isaka, M.; Kirtikara, K.; Tanticharoen, M.; Thebtaranonth, Y. Enniatin production by the entomopathogenic fungus Verticillium hemipterigenum BCC 1449. J. Antibiot. 2004, 57, 732-738. [CrossRef] [PubMed]

33. Song, H.H.; Ahn, J.H.; Lim, Y.H.; Lee, C. Analysis of beauvericin and unusual enniatins co-produced by Fusarium oxysporum fb1501 (kfcc 11363p). J. Microbiol. Biotechnol. 2006, 16, 1111-1119.

34. Ohshiro, T.; Matsudo, D.; Kazuhiro, T.; Uchida, R.; Nonaka, K.; Masuma, R.; Tomada, H. New verticilides, inhibitors of acyl-CoA:cholesterol acyltransferase, produced by Verticillium sp. FKI-2679. J. Antibiot. 2012, 65, 255-262. [CrossRef] [PubMed] 
35. Left, J.E.; Schröder, D.R.; Krishan, B.S.; Matron, J.A. Himastatin, a new antitumor antibiotic from Streptomyces hygroscopicus. II. Isolation and characterization. J. Antibiot. 1990, 43, 961-966.

36. Kamenecka, T.M.; Danishefsky, S.J. Template assembly of polyiodide networks at complexed metal cations: Synthesis and structures of $\left[\mathrm{Pd}_{2} \mathrm{Cl}_{2}\left([18] \mathrm{aneN}_{2} \mathrm{~S}_{4}\right)\right]_{1.5} \mathrm{I}_{5}\left(\mathrm{I}_{3}\right)_{2}$ and $\left[\mathrm{K}([15] \mathrm{aneO})_{5}\right] \mathrm{I}_{9}$. Angew. Chem. Int. Ed. 1998, 37, 293-295.

37. Kamenecka, T.M.; Danishefsky, S.J. Discovery through total synthesis: A retrospective on the himastatin problem. Chem. Eur. J. 2001, 7, 41-63. [CrossRef]

38. Zhan, J.; Burns, A.M.; Liu, M.X.; Faeth, S.H.; Gunatilaka, A.A.L. Search for cell motility and angiogenesis inhibitors with potential anticancer activity: Beauvericin and other constituents of two endophytic strains of Fusarium oxysporum. J. Nat. Prod. 2007, 70, 227-232. [CrossRef] [PubMed]

39. Vongvanich, N.; Kittakoop, P.; Isaka, M.; Trakulnaleamsai, S.; Vimuttipong, S.; Tanticharoen, M.; Thebtaranonth, Y. Hirsutellide A, a new antimycobacterial cyclohexadepsipeptide from the entomopathogenic fungus Hirsutella kabayasii. J. Nat. Prod. 2002, 65, 1346-1348. [CrossRef] [PubMed]

40. Dang, T.; Süssmuth, R.D. Bioactive peptide natural products as lead structures for medicinal use. Acc. Chem. Res. 2017, 50, 1566-1576. [CrossRef] [PubMed]

41. Kanaoka, M.; Isogai, A.; Murakoshi, S.; Ichinoe, M.; Suzuki, A.; Tamura, S. Bassianolide, a new insecticidal cyclodepsipeptide from Beauveria bassiana and Verticillium lecanii. Agric. Biol. Chem. 1978, 42, 629-635. [CrossRef]

42. Nakajko, S.; Shimizu, K.; Kometani, A. On the inhibitory mechanism of bassianolide, a cyclodepsipeptides, in acetylcholine-induced contraction in guinea-pig taenia coli. Jpn. J. Pharmacol. 1983, 33, 573-582. [CrossRef]

43. Jirakkakul, J.; Punya, J.; Pongpattanakitshote, S.; Paungmoung, P.; Vorapreeda, N.; Tachaleat, A.; Klomnara, C.; Tanticharoen, M.; Cheevadhanarak, S. Identification of the nonribosomal peptide synthetase gene responsible for bassianolide synthesis in wood-decaying fungus Xylaria sp. BCC1067. Microbiology 2008, 154, 995-1006. [CrossRef] [PubMed]

44. Romero, F.; Espliego, F.; Peérez Baz, J.; García de Quesada, T.; Grávalos, D.; De la Calle, F.; Fernández-Puentes, J.L. Thiocoraline, a new depsipeptide with antitumor activity produced by a marine Micromonospora. I. Taxonomy, fermentation, isolation, and biological activities. J. Antibiot. 1997, 50, 734-737. [CrossRef] [PubMed]

45. Uy, M.M.; Villanueva, M.P. The brine shrimp lethality of the leaf extracts of Piper baccatum Blume and their antioxidant properties. Asian J. Biol. Life Sci. 2015, 4, 179-184.

46. Mou, X.F.; Bian, W.T.; Wang, C.Y.; Shao, C.L. Secondary metabolites isolated from the sea hare Aplysia pulmonica from the South China Sea. Chem. Nat. Compd. 2016, 52, 758-760. [CrossRef]

47. Scudiero, D.A.; Shoemaker, R.H.; Paul, K.D.; Monks, A.; Tierney, S.; Nofziger, T.H.; Currens, M.J.; Seniff, D.; Boyd, M.R. Evaluation of a soluble tetrazolium/formazan assay for cell growth and drug sensitivity in culture using human and other tumor cell lines. Cancer Res. 1988, 48, 4827-4833. [PubMed]

48. Appendino, G.; Gibbons, S.; Giana, A.; Pagani, A.; Grassi, G.; Stavri, M.; Smith, E.; Rahman, M.M. Antibacterial cannabinoids from Cannabis sativa: A structure-activity study. J. Nat. Prod. 2008, 71, 1427-1430. [CrossRef] [PubMed]

49. Ellman, G.L.; Courtney, K.D.; Andres, V., Jr.; Featherstone, R.M. A new and rapid colorimetric determination of acetylcholinesterase activity. Biochem. Pharmacol. 1961, 7, 88-95. [CrossRef]

50. Bogurcu, N.; Sevimli-Gur, C.; Ozmen, B.; Bedir, E.; Korkmaz, K.S. ALCAPs induce mitochondrial apoptosis and activate DNA damage response by generating ROS and inhibiting topoisomerase I enzyme activity in K562 leukemia cell line. Biochem. Biophys. Res. Commun. 2011, 409, 738-744. [CrossRef] [PubMed]

51. Dewi, R.T.; Tachibana, S.; Fajriah, S.; Hanafi, M. $\alpha$-Glucosidase inhibitor compounds from Aspergillus terreus RCC1 and their antioxidant activity. Med. Chem. Res. 2015, 24, 737-743. [CrossRef]

(C) 2017 by the authors. Licensee MDPI, Basel, Switzerland. This article is an open access article distributed under the terms and conditions of the Creative Commons Attribution (CC BY) license (http://creativecommons.org/licenses/by/4.0/). 